\title{
Synthesis of Nano-sized Zinc Oxide and Its Application for Cellulosic Textiles
}

\author{
M.A. Ramadan ${ }^{1}$, S.H. Nassar ${ }^{1}$, A.S. Montaser*1, E.M. El- \\ Khatib ${ }^{1}$ and M.S.Abdel-Aziz ${ }^{2}$ \\ ${ }^{I}$ Textile Research Division and ${ }^{2}$ Microbial Chemistry \\ Department, NRC, Egypt.
}

\begin{abstract}
T $\mathrm{N}$ THIS article zinc oxide $(\mathrm{ZnO})$ nano-particles are synthesized through the alkali precipitation method using zinc acetate as a precursor and sodium hydroxide as basic source. The characterization of nanosized zinc oxide particles and their application in the pretreatment processes of cotton textiles have been studied for the resistance against bacteria and fungus, color strength enhancement and fastness properties improvement in addition to studying the effect of zinc oxide nano-particles incorporation into the printing paste on fixation method of the prints. The nanoparticles composition as well as their shape, size and crystallinity has been studied by transmission electron microscopy (TEM), X-Ray powder Diffraction (XRD). The synthesized $\mathrm{ZnO}$ nanoparticles have particle size lies between 200 $300 \mathrm{~nm}$ for the calcinated and higher than 400 for the dried one. The synthesized $\mathrm{ZnO}$ nano-particle shows antibacterial activity towards microorganisms (bacteria and fungi) and affects positively color fastness of printed fabrics, especially those treated with thermofixation process after printing. The results showed that the performances of zinc oxide as finishing agent can significantly improve printed cotton fabrics properties.
\end{abstract}

Keywords: Zinc oxide nanoparticles, Antibacterial, Steaming, Thermo-fixation

Adding new materials such as nano-metallic particles in the wet processing ${ }^{(1)}$ as, printing process is one of these methods. Depending on used dye, there are two major categories of the printing, reactive printing and pigment printing. The reactive printing has the priority for color depth and fastness properties. Nano-metallic particles have several uses in textile industry ${ }^{(2-5)}$ Zinc Oxide nanoparticles have several properties like high thermal conductivity, high refractive index, antibacterial, binding energy ${ }^{(6)}$, catalytic activity ${ }^{(7)}$ and UV- protection ${ }^{(8)}$. It is widely used in many materials and products. The products include medicine ${ }^{(9)}$, cosmetics, rubber, solar cells, foods, pigments ${ }^{(10)}$ and textiles finishing ${ }^{(11)}$.

There are several methods for synthesis of these $\mathrm{ZnO}$ nanoparticles powders such as alkali precipitation, thermal decomposition, hydrothermal synthesis, solgel methods ${ }^{(12)}$, microemulsions,spray pyrolysis, template-free method and other routes.

* Corresponding author email: abohabbiba2012@gmail.com 
Total -------------------------------1000 g

Sodium alginate $4 \%$ was used as thickening agent ${ }^{(17)}$

NB: $.0 .8 \mathrm{mg}$ of Zinc Oxide dispersed in one liter of Ethylene glycol (EG/Water) $(65 / 35)$ to produce $1 \mathrm{ppm}$.

\section{Printing procedure}

Printing was carried out by the conventional screen printing technique. Samples printed with the prepared printing pastes containing reactive dye were first dried and then fixated by two ways: a) Steam-fixation: printed samples fixated by steaming at $120-123^{\circ} \mathrm{C}$ for $10 \mathrm{~min}$. and b) Thermo-fixation: printed samples thermo fixated at $130^{\circ} \mathrm{C}$ for $3.5 \mathrm{~min}$. The fixation of dye on the fabric carried out at atmospheric pressure ${ }^{(17)}$.

\section{Washing}

Washing process of the prints was carried out through four stages: 1)rinsing thoroughly with cold water, 2) washing with hot water , 3) soaping using $2 \mathrm{~g} / \mathrm{l}$ non-ionic detergent namely Espycon 1030at $90-95^{\circ} \mathrm{C}$ for $15 \mathrm{~min}$. and 4) washing with hot water. The samples were dried and assessed for color strength and overall fastness properties.

\section{Color strength $(K / S)$ and fastness}

Color strength expressed as(K/S), and the fastness properties, washing, perspiration and rubbing, were assessed according to standard methods ${ }^{(18)}$.

\section{Antibacterial activity}

Zinc oxide nanoparticles were tested on Pseudomonas arauginosa [ATCC 27853] and Staphylococcus aureus [ATCC 6538-P] by zone of inhibition experiment in addition to Asperagillus niger [NRRL A-326] as a type of fungi which kindly supplied from Microbiological Department, NRC, Egypt . Nutrient agar was poured onto the Petri dishes and allowed to solidify. Bacteria and fungi were spread on three different plates uniformly. Zinc oxide nanoparticles were gently placed over the solidified agar gel. Plates were incubated at $37^{\circ} \mathrm{C}$ for $24 \mathrm{hr}$ to check the zone of inhibition ${ }^{(19,20)}$.

\section{Results and Discussions}

$X$-ray diffraction spectrometry

Zinc acetate reacts with sodium hydroxide forming weight precipitate of zinc hydroxide and sodium acetate, the obtained precipitate was washed with water to remove sodium acetate. The obtained hydroxide drying at $100^{\circ} \mathrm{C}$ forming metal alkoxide followed by calcinations at $400^{\circ} \mathrm{C}$ for $3 \mathrm{hr}$ cleavage the alkoxide chains forming metal oxide nanoparticles. We can describe the zinc oxide formation with the reaction below ${ }^{(13)}$.

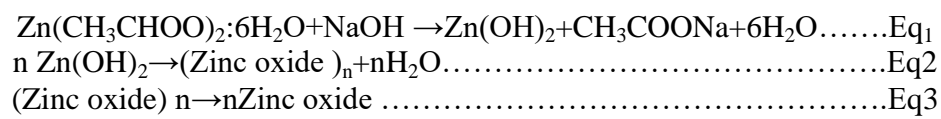


Figure $1(\mathrm{a}, \mathrm{b})$ shows the XRD data of the dried zinc oxide and zinc oxide nanoparticles calcined after the drying process at $400{ }^{\circ} \mathrm{C}$. All of the XRD plots of the composites show peaks from the pure hexagonal structure of zinc oxide. Three reflections (100), (002) and (101) have been observed, which are similar to the observed reflections in zinc oxide bulk. The diffraction peaks obtained at $31.84^{\circ}, 34.52^{\circ}, 36.33^{\circ}, 47.63^{\circ}, 56.71^{\circ}, 62.96^{\circ}, 68.13^{\circ}$, and $69.18^{\circ}$ are strong and narrow indicating that the nano-crystalline zinc oxide NPs has good crystallinity. The highest intensity at Fig. 1b related to zinc oxide nanoparticles express the sample particles size reflecting the nano-range size which appears after by particle size analyzer. Also, characteristic peaks of the zinc oxide phase increase in intensity at $400^{\circ} \mathrm{C}$ with the calcination temperature. The calcined sample may be more purified at this temperature because of losing traces of $\mathrm{CH}_{3} \mathrm{COONa}$ after washing, which decomposed gradually with increasing the temperature. The pure phase of zinc oxide was formed at $400^{\circ} \mathrm{C}^{(13)}$


Fig. 1. XRD analysis of (a) $\mathrm{ZnO}$ nanoparticles dried at $100{ }^{\circ} \mathrm{C}$, (b) $\mathrm{ZnO}$ nanoparticles calcinated at $400^{\circ} \mathrm{C}$.

Egypt. J. Chem. 59, No. 4 (2016) 


\section{Transmittance electron microscopy}

TEM photograph of nanocrystalline zinc oxide nanoparticles at two different temperatures are shown in Fig.2. Sample (Fig. 2a) prepared the precursors of zinc oxide powder at $100^{\circ} \mathrm{C}$. The produced powder was amorphous zincite with a nearly spherical structure. The calcinated zinc oxide (Fig. 2b) nanoparticle at $400^{\circ} \mathrm{C}$ shows homogenous hexagonal structure. It is expected that the temperature of calcinations assist purification and degradation of metal alkoxide bonds forming homogenous and crystalline zinc oxide nanoparticles, it's also expected that water residues completely removed up $100^{\circ} \mathrm{C}$ affect crystallinity of the produced zinc oxide nanoparticles, it means at $400^{\circ} \mathrm{C}$ completely removing of water molecules. The results of TEM are consistent with the observation from XRD ${ }^{(13)}$

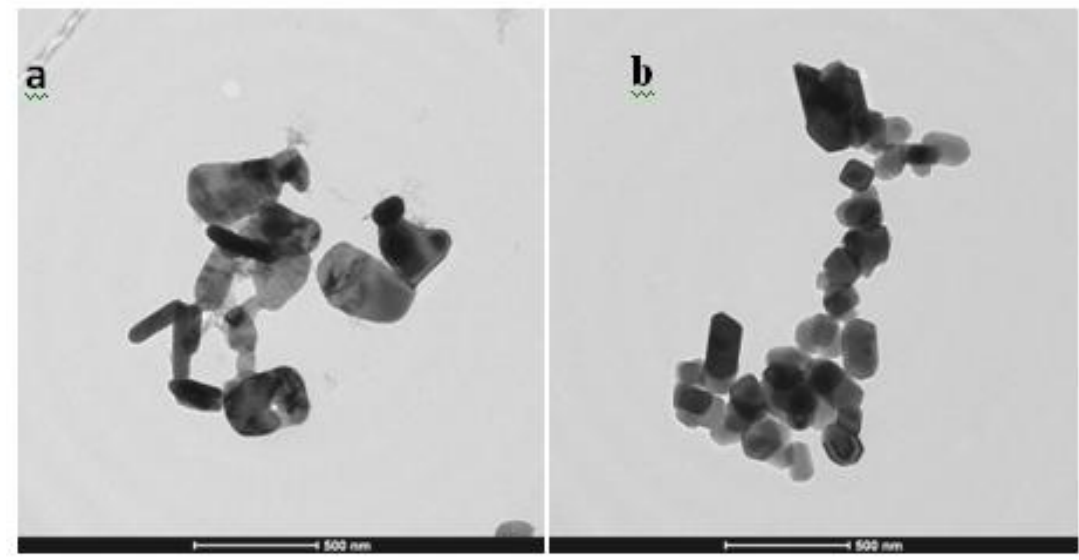

Fig. 2. TEM images of (a) $\mathrm{ZnO}$ nanoparticles dried at $100^{\circ} \mathrm{C}$, (b) $\mathrm{ZnO}$ nanoparticles calcinated at $400^{\circ} \mathrm{C}$.

\section{Particle size analyzer}

Figure 3 showed increase in the particle size crystal for zinc oxide nanoparticles dried at $100^{\circ} \mathrm{C}$ over the calcined zinc oxide nanoparticles at $400^{\circ} \mathrm{C}$. The particle size analyzer Fig. 3a shows the widely distributed size for zinc oxide nanoparticles dried at $100{ }^{\circ} \mathrm{C}$ are lying between $700-900 \mathrm{~nm}$. On the other hand, Fig. $3 \mathrm{~b}$ shows boarded distributed size for calcined zinc oxide nanoparticles at $400^{\circ} \mathrm{C}$ which decreases to $250 \mathrm{~nm}$. The two prepared forms of zinc oxide nanoparticles lie in submicron. The depression at size with high temperature attributed to temperature effect at removing traces of zinc oxide nanoparticles reaction and completely removing of moisture from internal network of the produced zinc oxide nanoparticles crystal $\left({ }^{13)}\right.$. 

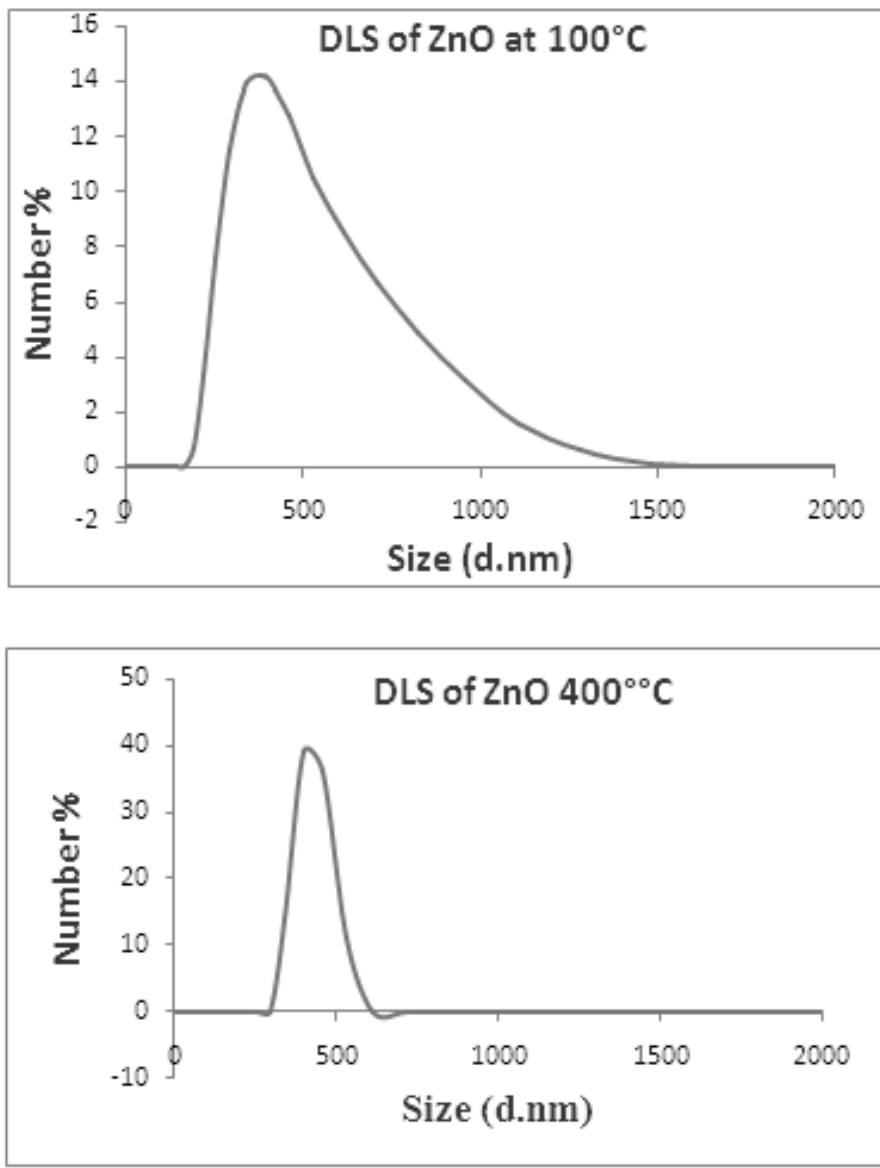

Fig. 3. Particle size analyzer of (a) $\mathrm{ZnO}$ nanoparticles dried at $100^{\circ} \mathrm{C}$, (b) $\mathrm{ZnO}$ nanoparticles calcinated at $400^{\circ} \mathrm{C}$.

Antibacterial activity of zinc oxide nanoparticles

In Fig. 4 zinc oxide nanoparticles exhibited remarkable antibacterial activity and demonstrated a lethal effect against all types of microorganisms, disc zone method shows inhibition zone of zinc oxide nanoparticles $12-15 \mathrm{~mm}$ toward microorganisms even at low concentrations. As known a plausible mechanism of zinc oxide inactivation of bacteria involves the direct interaction between zinc oxide nanoparticles and cell surfaces, which affects the permeability of membranes where nanoparticles enter and induce oxidative stress in bacterial cells, subsequently resulting in the inhibition of cell growth and eventually in cell death $^{(21)}$.

Egypt. J. Chem. 59, No. 4 (2016) 

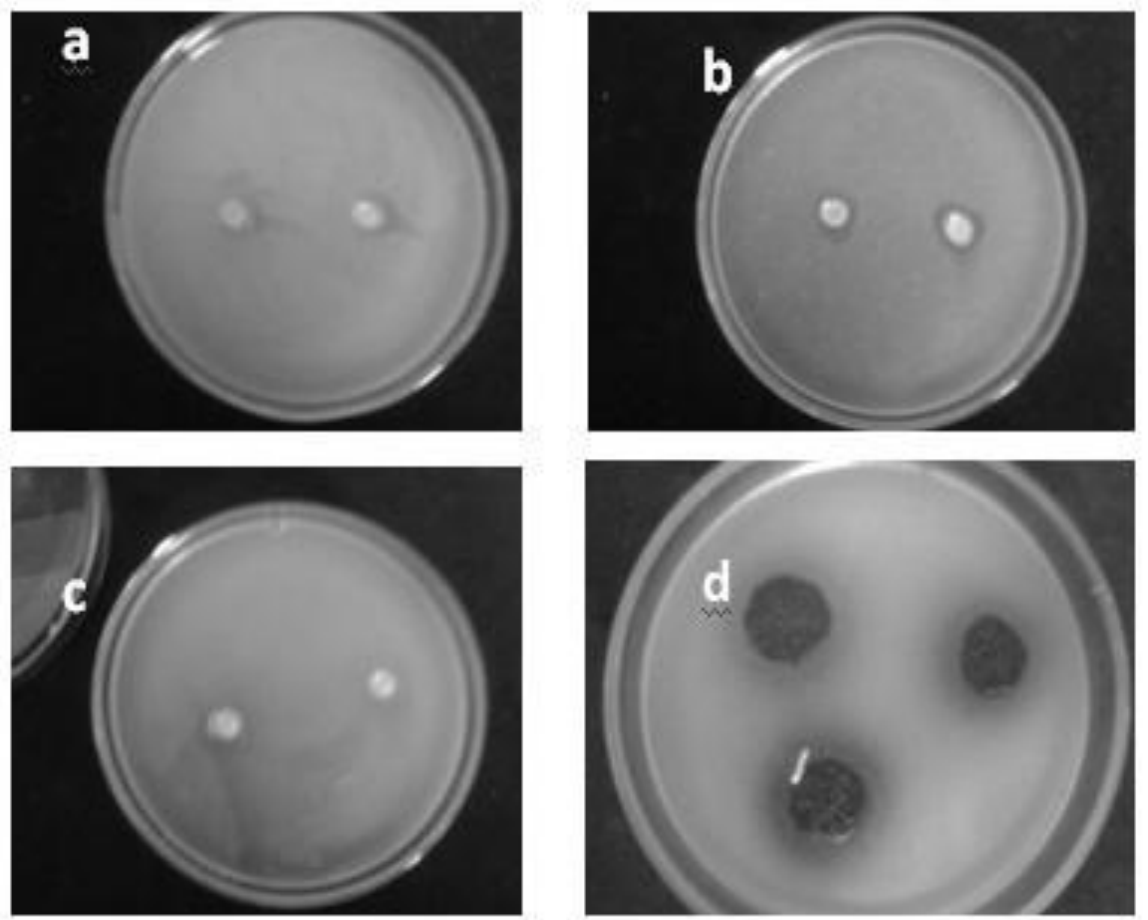

Fig. 4. antibacterial activity of zinc oxide nanoparticles against a) Staphylococcus aureus, b) Pseudomonas arauginosa, c) Aspergillus - niger and d) Printed sample against Pseudomonas arauginosa.

Effect of zinc oxide nanoparticles concentration on overall fastness properties of printed fabrics

Four different concentrations of zinc oxide nanoparticles $200-500 \mathrm{ppm} / \mathrm{kg}$ printing paste were used in printing pastes studying their color effect. Various printing pastes containing the zinc oxide nanoparticles and reactive dye applied to cotton fabrics using silk screen printing process. Table 1 shows the effect of zinc oxide nanoparticles concentration on some overall fastness properties and color strength of dried and steam-fixated printed fabrics.

It is clear from Fig. 5 that incorporation of zinc leads to significant enhancement in color strength $(\mathrm{K} / \mathrm{S})$. oxide nanoparticles.

The overall fastness properties of the prints are acceptable regardless of the zinc oxide nanoparticles concentration. Zinc oxide nanoparticles used to be known as photocatalytic material which can absorb UV-vis light followed by electron excitation. These exited electrons affect the resonance of color and showed positive effect on color fastness.

Egypt. J. Chem. 59, No.4 (2016) 
TABLE 1. Effect of ZnO NPs concentration on overall fastness properties and color strength of dried and steamed printed fabrics.

\begin{tabular}{|c|c|c|c|c|c|c|c|c|c|}
\hline \multirow{3}{*}{$\begin{array}{l}{[\mathrm{ZnO} O} \\
(\mathbf{p p m})\end{array}$} & \multirow{3}{*}{$\mathbf{K} / \mathbf{S}$} & \multicolumn{2}{|c|}{$\begin{array}{l}\text { Washing } \\
\text { fastness }\end{array}$} & \multicolumn{2}{|c|}{$\begin{array}{l}\text { Rubbing } \\
\text { fastness }\end{array}$} & \multicolumn{4}{|c|}{ Perspiration fastness } \\
\hline & & \multirow[b]{2}{*}{ Alt } & \multirow[b]{2}{*}{ St } & \multirow[b]{2}{*}{ wet } & \multirow[b]{2}{*}{ dry } & \multicolumn{2}{|c|}{ Acidic } & \multicolumn{2}{|c|}{ Alkaline } \\
\hline & & & & & & Alt & St & Alt & St \\
\hline 0 & 10.14 & 4 & $4-5$ & $3-4$ & 4 & 4 & $4-5$ & $4-5$ & $4-5$ \\
\hline $200 \mathrm{ppm}$ & 10.94 & 4 & 4 & 4 & 4 & 4 & $4-5$ & $4-5$ & $4-5$ \\
\hline $300 \mathrm{ppm}$ & 11.63 & 4 & $4-5$ & $3-4$ & 4 & 4 & $4-5$ & $4-5$ & $4-5$ \\
\hline 400ppm & 13.54 & 4 & $4-5$ & $3-4$ & 4 & 4 & $4-5$ & $4-5$ & $4-5$ \\
\hline $500 \mathrm{ppm}$ & 12.30 & 4 & $4-5$ & 4 & 4 & 4 & $4-5$ & $4-5$ & $4-5$ \\
\hline
\end{tabular}

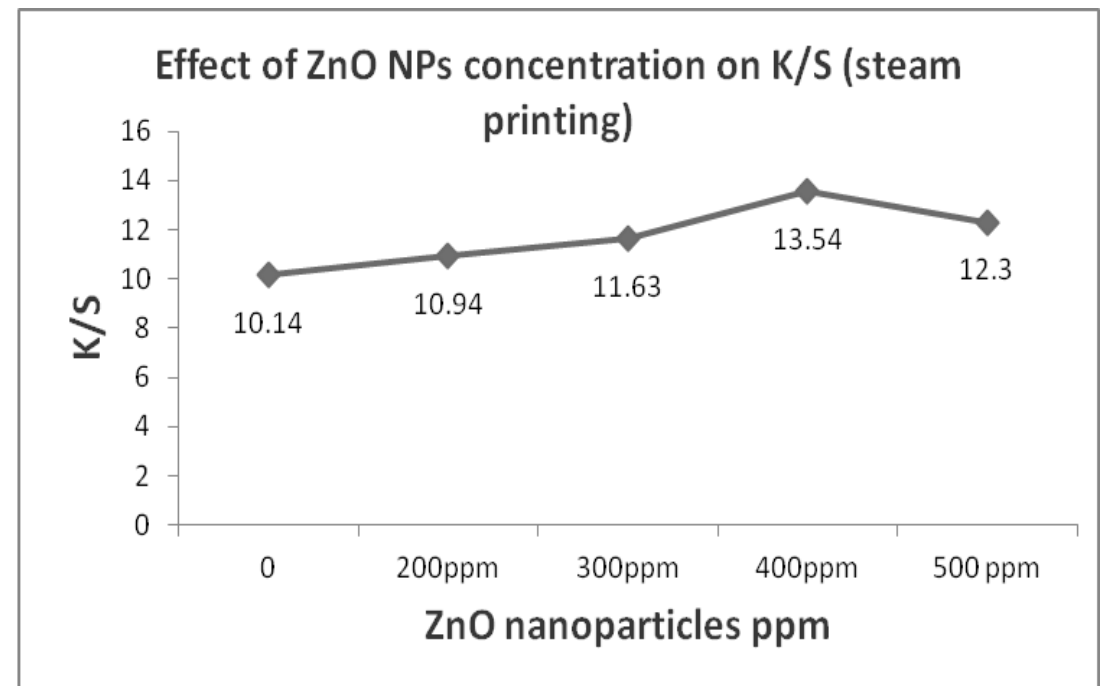

Fig. 5. Effect of ZnO NPs concentration on K/S (steam printing) .

Table 2 shows the effect of zinc oxide nanoparticles concentration on the printability of dried and thermo-fixated printed fabrics. Reactive printing with Drimarin blue $\mathrm{P}$ dye was carried out using different concentrations of zinc oxide nanoparticles, according to the recipe given in the Experimental section. The printed samples were assessed for color strength $(\mathrm{K} / \mathrm{S})$ and some overall fastness properties and the results obtained are summarized in Fig. 6. It is seen that by increasing zinc oxide nanoparticles concentration (with constant amount of dye) into printing paste the color strength increases significantly. On the other hand some of overall fastness properties affect positively color fastness.

Egypt. J. Chem. 59, No. 4 (2016) 
TABLE 2. Effect of ZnO NPs concentration on the printability of thermo-fixated printed fabrics.

\begin{tabular}{|c|c|c|c|c|c|c|c|c|}
\hline \multirow{3}{*}{$\begin{array}{l}\text { [ZnO] } \\
(\mathbf{p p m})\end{array}$} & \multicolumn{2}{|c|}{ Washing fastness } & \multicolumn{2}{|c|}{$\begin{array}{l}\text { Rubbing } \\
\text { fastness }\end{array}$} & \multicolumn{4}{|c|}{ Perspiration fastness } \\
\hline & \multirow[b]{2}{*}{ Alt } & \multirow[b]{2}{*}{ St } & \multirow[b]{2}{*}{ wet } & \multirow[b]{2}{*}{ dry } & \multicolumn{2}{|c|}{ Acidic } & \multicolumn{2}{|c|}{ Alkaline } \\
\hline & & & & & Alt & $\mathbf{S t}$ & Alt & St \\
\hline 0 & 4 & 4.5 & $3-4$ & 4 & 4 & 4.5 & 4 & 4.5 \\
\hline 200 ppm & 4 & 4.5 & $3-4$ & $4-5$ & 4 & 4.5 & 4 & 4.5 \\
\hline 300ppm & 4 & 4 & 4 & $4-5$ & 4 & 4 & 4 & 4.5 \\
\hline 400ppm & 4 & 4.5 & $4-5$ & $4-5$ & 4 & 4.5 & 4 & 4.5 \\
\hline $500 \mathrm{ppm}$ & 4 & 4 & 4 & $4-5$ & 4 & 4.5 & 4 & 4.5 \\
\hline
\end{tabular}

Alt: Alteration , St: Staining on cotton

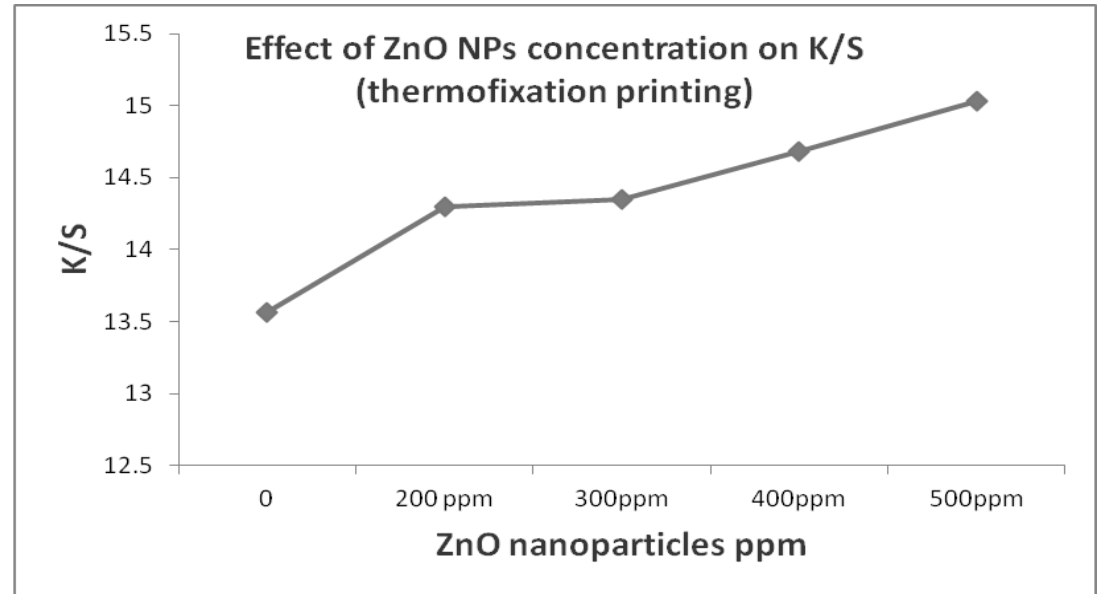

Fig. 6. Effect of $\mathrm{ZnO}$ NPs concentration on K/S (thermo-fixation printing).

Figure 7 shows the effect of zinc oxide nanoparticles incorporate in the printing paste on the used fixation method for the prints. This was evaluated via determining the color strength of the prints.

It is observed (Fig. 7) that the color strength (K/S) is significantly improved by thermo-fixation method regardless of the zinc oxide nanoparticles concentration. That may be because steam boiled vapor may react with zinc oxide nanoparticles forming zinc hydroxide reduced the color fastness. 


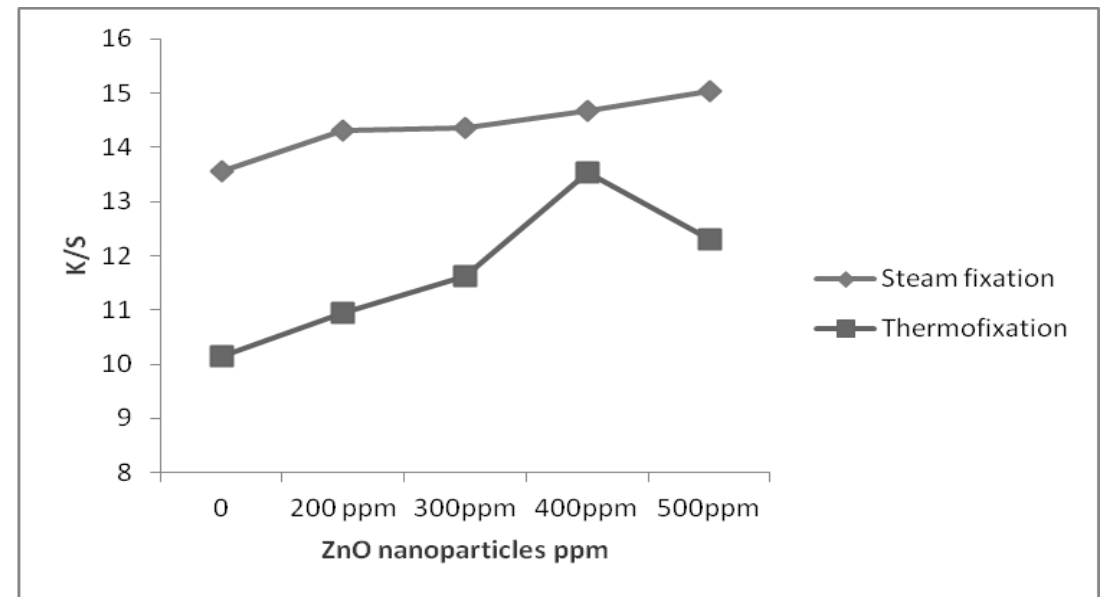

Fig. 7. Effect of $\mathrm{ZnO}$ NPs concentration on $\mathrm{K} / \mathrm{S}$ at steam and thermo-fixation printing.

\section{Conclusion}

Zinc oxide nanoparticles are successfully prepared by alkaline precipitation. The obtained nanoparticles were deduced by spectroscopic techniques TEM and XRD. The obtained zinc oxide nanoparticles lied in nano-size between 200-300 $\mathrm{nm}$. The obtained zinc oxide nanoparticle shows antibacterial activity towards microorganisms (bacteria and fungi). Zinc oxide nanoparticles affect positively color fastness of printed fabrics, especially those treated with thermo-fixation process after printing.

\section{References}

1. Hebeish, A., et al., Highly effective antibacterial textiles containing green synthesized silver naoparticles. Carbohydrate Polymers, 86(2), P. 936-940(2011).

2. Hebeish, A.M.A.R., Montaser, A. S., Salama, Abeer AA. and Abdel-Aziz, M., In vitro and in vivo antibacterial potential of chitosan-g-acrylonitrile silver nanocomposite against a pathogenic bacterium. Int. J. Curr. Microbiol. App. Sci., 4(3), p. 5-19 (2015).

3. Hebeish, A.M.A.R., Montaser, A.S., Krupa, I. and Farag, A.M., Molecular characteristics and antibacterial activity of alginate beads $\mathrm{c}$ oated chitosan polyacrylonitrile copolymer loaded silver nanocomposite. Journal of Scientific Research and Reports, 5(6), p. 479-488 (2015).

4. Hebeish, A., et al., Establishment of optimum conditions for preparation of silver nanoparticles using carboxymethyl chitosan. Egyptian Journal of Chemistry, 56(3), (2013).

Egypt. J. Chem. 59, No. 4 (2016) 
5. Hebeish, A., et al., Preparation, characterization and antibacterial activity of chitosang-poly acrylonitrile/silver nanocomposite. International Journal of Biological Macromolecules, 68, p. 178-184 (2014).

6. Jones, N., et al., Antibacterial activity of $\mathrm{ZnO}$ nanoparticle suspensions on a broad spectrum of microorganisms. FEMS Microbiol Lett, 279(1), p. 71-6 (2008).

7. Sahoo, G.P., et al., Hydrothermal synthesis of hexagonal $\mathrm{ZnO}$ microstructures in HPMC polymer matrix and their catalytic activities. Journal of Molecular Liquids, 212, p. 665-670 (2015).

8. Ramasamy, M., et al., Synthesis of silica coated zinc oxide-poly(ethylene-co-acrylic acid) matrix and its UV shielding evaluation. Materials Research Bulletin, 51, p. 85$91(2014)$

9. Malini, M., et al., A versatile chitosan $/ \mathrm{ZnO}$ nanocomposite with enhanced antimicrobial properties. International Journal of Biological Macromolecules,. 80, 121-129 (2015).

10. Ibrahim, N.A., et al., Combined UV-protecting and reactive printing of Cellulosic/wool blends. Carbohydrate Polymers, 92(2),1386-1394 (2013).

11. Kundu, D., et al., Extracellular biosynthesis of zinc oxide nanoparticles using Rhodococcus pyridinivorans NT2: Multifunctional textile finishing, biosafety evaluation and in vitro drug delivery in colon carcinoma. Journal of Photochemistry and Photobiology B: Biology, 140, 194-204 (2014).

12. Mote, V.D., Purushotham, Y. and Dole, B.N., Structural, morphological, physical and dielectric properties of $\mathrm{Mn}$ doped $\mathrm{ZnO}$ nanocrystals synthesized by sol-gel method. Materials \& Design, 96, 99-105 (2016).

13. Rezende, C.P., Silva, J.B.D. and N.D.S., Mohallem, Influence of drying on the characteristics of zinc oxide nanoparticles. Brazilian Journal of Physics, . 39, 248-251 (2009).

14. Přichystalová, H., et al., Synthesis, characterization and antibacterial activity of new fluorescent chitosan derivatives. International Journal of Biological Macromolecules. 65: p. 234-240 (2014).

15. Abdel-Mohsen, A.M., et al., Biomedical textiles through multifunctioalization of cotton fabrics using innovative methoxypolyethylene glycol-N-chitosan graft opolymer. Journal of Polymers and the Environment, 20(1), 104-116 (2012).

16. Abdel-Mohsen, A.M., et al., Antibacterial cotton fabrics treated with core-shell nanoparticles. International Journal of Biological Macromolecules, 50 (5), 1245-1253 (2012).

17. Fijan, R., et al., Rheological properties of printing pastes and their influence on quality-determining parameters in screen printing of cotton with reactive dyes using recycled polysaccharide thickeners. Carbohydrate Polymers, 78(1), 25-35 (2009). 
18. Hebeish, A., et al., Dependence of reactive prints of cotton fabrics on type and condition of the scouring system. The Journal of The Textile Institute, 101(12),11061111(2010)

19. Abdel-Mohsen, A.M., et al., Antibacterial activity and cell viability of hyaluronan fiber with silver nanoparticles. Carbohydrate Polymers, 2013 92(2), 1177-1187.

20. Abdel-Mohsen, A.M., et al., Green synthesis of hyaluronan fibers with silver nanoparticles. Carbohydrate Polymers, 89(2), 411-422 (2012).

21. Xie, Y., et al., Antibacterial activity and mechanism of action of zinc oxide nanoparticles against Campylobacter jejuni. Appl Environ Microbiol, 77(7), 2325-31 (2011).

(Received 20/4/2016;

accepted 10/5/2016)

Egypt. J. Chem. 59, No. 4 (2016) 


\section{تحضير جسيمات أكسيد الزنك النانومترية وتطبيقها على الأقمشة

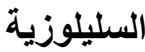

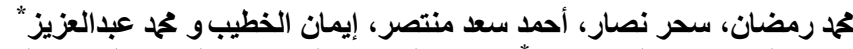
شعبة الصناعات النسيجية و * شعبة الهندسة الور اثية و البيوتكنولوجى الفئ المركز

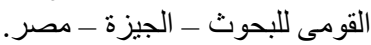

فى هذه الدراسة تم تحضير جسيمات أكسيد الزنك النانومنرية بواسطة طريقة

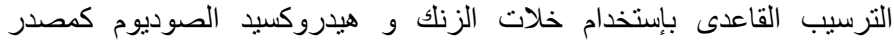

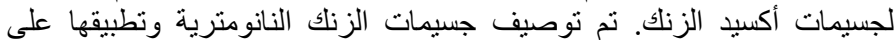

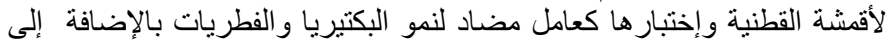

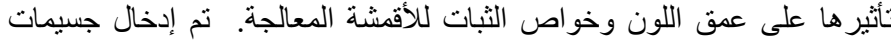

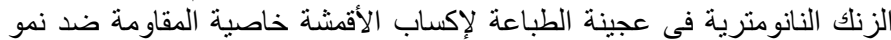

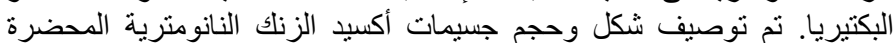

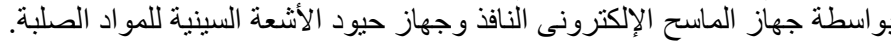

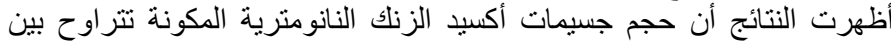

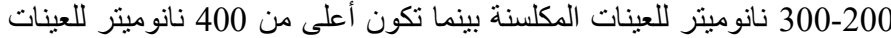

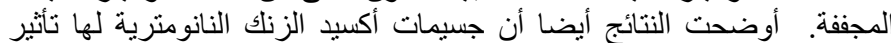

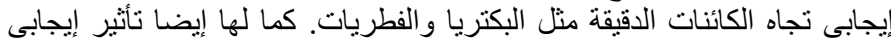

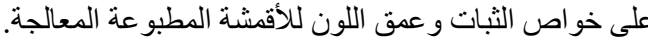

